\title{
Financial distress as a moderating variable of the influence of audit opinion and public accounting firm size on voluntary auditor switching
}

$$
\text { Choirul Huda, }{ }^{1} \text { Ratno Agriyanto, }{ }^{2}
$$

Herwening Sindu Lestari, ${ }^{3}$ Bill Pangayow ${ }^{4}$

1,2,3Universitas Islam Negeri Walisongo Semarang, Indonesia

${ }^{4}$ College of Business Administration and Accountancy, Philippines Christian University, Philippines email: choirul979@gmail.com

\begin{abstract}
Purpose - This study aims to examine the effect of financial distress as a moderator of the effect of audit opinion and public accounting firm (KAP) size on auditor switching in companies listed on the Jakarta Islamic Index (JII) for the 2014-2019 period.
\end{abstract}

Method - This study uses a sample of companies listed on the Jakarta Islamic Index (III) for the 2014-2019 period. The number of companies sampled in this study were 12 companies. In this study, the researchers used a quantitative type of model and used the Statistical Package for Social Science (SPSS) version 16 for analyzing the data.

Result - The results show that audit opinion and public accounting firm size have no effect on auditor switching, financial distress is not able to moderate the effect of audit opinion with auditor switching, and financial distress is not able to moderate the relationship between public accounting firm size and auditor switching.

Implication - For stakeholders in motivating management to retain or replace auditors from various factors that are considered including audit opinion, public accounting firm size and financial distress.

Originality - The object used in this study is a list of companies registered on JII. There is a 2-year additional period from the previous study, which was 4 years to 6 years. The measuring instrument for the financial distress variable used in this study is the Altman Z-score.

Keywords: auditopinion; public accounting firm size; financial distress; auditor switching 
Choirul Huda, Ratno Agriyanto, Herwening Sindu Lestari, Bill Pangayow

\section{Introduction}

Go-Public companies are companies that offer shares to the public or the public to be owned and listed on the Indonesian stock exchange. One of the JIAFR | 156 obligations of go-public companies is to publish financial statements that have been audited by an independent auditor every year. Its purpose is to provide financial information about the company that is useful to current and potential investors in their capacity as providers of capital (Kieso et al., 2007). Agencies that provide services as auditors are needed to ensure the fairness of a published financial report.

The auditor is an independent party who is considered capable of being an intermediary because of the difference in interests between the principal (investor) and the agent, namely management as the manager of the company. Company management must prepare financial statements in a relevant and honest manner. The task of the auditor is to examine and provide an opinion on the financial statements of the client company. All auditors must have a high independent spirit to maintain the trust of users of financial statements, but this trust to auditors has decreased due to events such as many accounting scandals carried out by several companies. The companies involved in the accounting scandal include: (1) PT. Railways in 2006 which should have been in a loss but reported a profit, (2) Bank BRI Jambi branch in 2010 had bad debts up to Rp 52 billion which was suspected by a public accountant to be involved in the case, (3) members of the General Elections Commission (KPU) allegedly bribed members of the Financial Supervisory Agency (BPK) who carried out a financial audit of election logistics at that time, (4) Bank Syariah Mandiri in 2014 lost Rp 50 billion due to the action of embezzlement and falsification of data, and (5) in 2019 PT. Garuda Indonesia Tbk (GIAA) manipulated financial statements; the company's management allegedly planned the fraud by voluntary auditor switching three times in 5 years.

In 2003, the Indonesian government issued a regulation regarding auditor switching. Three Decrees of the Minister of Finance No. 
Financial distress as a moderating variable of the influence of audit opinion ...

423/KMK.06/2002 (article 6) were issued which was later amended through the Decree of the Minister of Finance No. 359/KMK.06/2003 concerning Public Accountant Services (article 2). These regulations were later refined by regulators and resulted in new regulations. In 2008, through the Minister of Finance Regulation No.17/PMK.01/2008 concerning Public Accountant Services (article 3), which contains the provision of general audit services on the financial statements of an entity, Public Accountant is carried out for a maximum of 6 (six) consecutive financial years and by a Public Accountant for a maximum of 3 (three) consecutive financial years (Wawo et al., 2017). There is a regulatory update with Law no. 5 of 2011 containing the deadline for changing the Public Accountant Firm for a duration of 5 years and can be extended. The regulation was updated again through Government Regulation No. 20/2015 which states that the rules for rotation of public accounting firms carried out by companies are limited to a maximum of 5 consecutive financial years.

Audit switching is a change from one public accounting firm (auditor) to another public accounting firm (auditor) carried out by the client company (Oktaviana et al., 2017). Audit switching is carried out on two grounds, namely mandatory and voluntary. The decision to perform voluntary audit switching is very interesting to study, because there are many factors behind the companies in making the decision to change the public accountant firm or auditor.

An audit opinion is an opinion or statement given by the auditor to the client company's financial statements, after the auditor examines the findings contained in the company's financial statements for their fairness (Putra \& Suryanawa, 2016). The company's management always wants an unqualified opinion from the auditor for the company's financial statements. Audit opinion can be used as a factor for the company's consideration to perform auditor switching. Companies will tend to make auditor changes, which allow them to get an opinion that matches what the company wants. Research conducted by Putra and Suryawana (2016) and Yusriwarti (2019) found that audit opinion has an effect on auditor switching. However, a research 
conducted by Wea and Murdiawati (2015), audit opinion has no effect on auditor switching.

The size of a public accounting firm is used to measure its reputation (Manto \& Wanda, 2018). Companies will prefer public accounting firms that have a better reputation to improve the company's financial statements in the eyes of investors and creditors. Companies that have used the services of public accounting firms that are already affiliated with the Big Four tend to be reluctant to perform audit switching. Research conducted by Manto and Wanda (2018) and Oktaviana (2017) obtained the results that public accounting firm size affects audit switching. In contrast, the research conducted by Putra and Suryanawa (2016) found that the size of the public accounting firm size has no effect on audit switching.

The existence of inconsistent research results with each other requires contingency approach to reconcile the differences between the various studies (Govindarajan, 1986). The approach aims to add a moderating variable. The moderating variable used in this study is financial distress. Financial distress is a condition of insolvency when the company cannot fulfill the company's obligations with the company's operating results. Bankruptcy of a company can be caused because the company is unable to overcome a problem of financial difficulties (Putra \& Suryanawa, 2016). The impact is that it can harm investors, creditors and suppliers. From an economic point of view, the company has experienced a failure in running its business. Companies can anticipate the occurrence of financial distress if they predict and analyze the company's financial health level.

Financial distress is a condition experienced by companies when experiencing financial difficulties (Putra \& Suryanawa, 2016). In this condition, the company will take the initiative to change auditors with the purpose of avoiding or switching from a public accounting firm with a large audit fee to a new public accounting firm with a smaller audit fee. Research conducted by Manto and Wanda (2018) and Yusriwarti (2019) found that financial distress has an effect on audit switching. However, a research 
conducted by Susanto (2018) found that financial distress has no effect on audit switching.

This study refers to the research that has been done by Putra and Suryanawa (2016) entitled the Effect of Audit Opinion and Reputation of Public Accounting Firms on Auditor Switching with Financial Distress as a Moderating Variable. The similarity to Putra and Suryanawa (2016) research is that it has the same independent, dependent and moderator variables. The differences are: the objects used in this study are companies registered in JII, the 2-year additional period from the previous study, which becomes 6 years, and the measuring instrument for the financial distress variable used in this study is the Altman Z-score. The Altman Z-score measuring instrument has the best predictor in measuring the company's financial difficulties in academic studies (Nasser et al., 2006).

Based on the explanation of the issues and phenomena that have been stated above, by adding a moderating variable in the form of financial distress and the object of research on companies listed on the Jakarta Islamic Index with the observation period from 2014 to 2019, the researchers conducted a study on financial distress as a moderating variable of the effect of audit opinion and public accounting firm size on voluntary auditor switching.

\section{Literature Review}

\section{Agency theory}

Agency theory is a relationship in which a contract or agreement occurs between one party, namely the owner of the company (principal) and another party, namely the management of the company/agent (Jensen \& Meckling, 1976). A cooperative relationship with different interests will cause conflict between the agent and the principal. The conflict of interest between the agent and the principal is caused by the separation of duties and information asymmetry.

Prevention of conflicts of interest between the agent and the principal requires an independent auditor as an intermediary to supervise and control 
the actions of the agent to comply with the contract or agreement that has been mutually agreed upon by the principal. Auditors are third parties who are able to bridge the interests of both parties (agents and principals) in providing actual financial reporting information.

\section{Auditor Switching}

Auditor switching is a change in public auditors carried out by the company (Mulyadi, 2014). Auditor switching carried out by companies has two characteristics; mandatory and voluntary. Mandatory is done because of regulations that require companies to change auditors. Meanwhile, auditor switching is done voluntarily because it is based on management's wishes outside the time in the stipulated rotation rules. Mardiyah (2003) states that two factors that influence companies to do auditor switching voluntarily are Client-related Factors, namely: financial difficulties, failed management, changes in ownership, and IPO; and Auditor-related Factors, namely: audit fees and audit quality.

\section{Financial Distress}

The company's financial statements describe the actual conditions of the company that will be used by users in making decisions. When the financial statements provide information that total liabilities are more than total equity, then the company can be said to be experiencing instability regarding the company's financial health. Financial distress has several meanings, including: a) Economic distress (economic failure), economic failure is company's money loss or the company's income is unable to cover its costs. b) Financial distress (financial failure), financial distress is a financial difficulty that is being experienced by the company in the form of a lack of cash or working capital (Halim \& Mahmud, 1997).

\section{Audit Opinion}

The audit opinion is the final result of the audit procedure process provided by the auditor in the form of an opinion on the company's financial 
statements. According to Mulyadi (2014), there are various types of audit opinion, including: a) Unqualified opinion, b) Unqualified opinion report with explanatory language, c) Qualified opinion, d) Unreasonable opinion (adverse opinion), e) Disclaimer of opinion.

\section{Public Accounting Firm Size}

Public accounting firms have the legal right to conduct audits that have been determined by regulations in each country. Public accounting firms can be grouped into two types, namely large public accounting firms and small public accounting firms. A public accounting firm is considered large if it cooperates with the Big Four, has branches and has professional staff of more than 25 people. Meanwhile, small public accounting firms are the opposite. They do not cooperate with the Big Four, do not have branches and only have less than 25 professional staff (Riyatno, 2007).

\section{Sharia Capital Market}

The Islamic capital market is a capital market that trades financial instruments based on rules in sharia principles. Sharia principles consist of the prohibition of usury, the prohibition of gharar, the prohibition of maysir and companies registered in the sharia capital market do not own businesses that are prohibited by sharia (Qoyum, 2018).

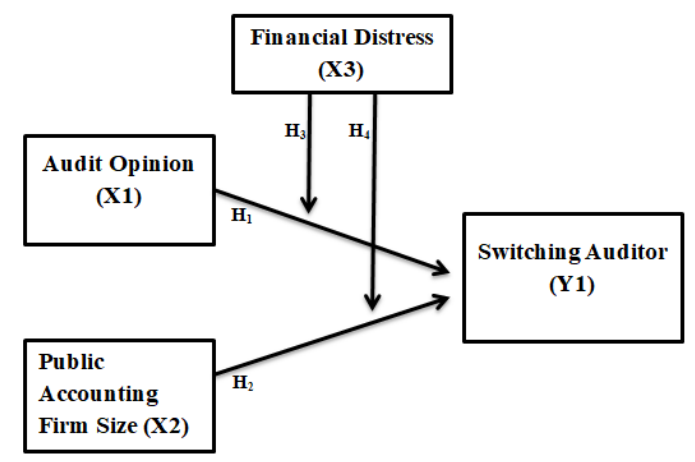

Figure 1. Research Framework 
Choirul Huda, Ratno Agriyanto, Herwening Sindu Lestari, Bill Pangayow

\section{Hypothesis Development}

The management has the authority to manage the company to be accountable to shareholders through financial statements. The audit opinion on the financial statements is an independent party's opinion that reflects the actual condition of the company. Management basically does not like audit opinions other than unqualified because it can affect the trust and view of management's performance in managing the company. Companies that do not get an audit opinion other than unqualified will tend to do auditor switching. This statement is supported by research conducted by Yusriwarti (2019), Susanto (2018) and Ikmala (2018) that the results of these studies are audit opinion variables that affect auditor switching.

\section{$H_{1}$ : audit opinion has an effect on auditor switching}

Users of financial statements will have more confidence in the performance of auditors from large public accounting firms, especially those that have collaborated with the Big Four. Large public accounting firms have a better reputation than small public accounting firms. Large public accounting firms also have many clients and professional resources that make public accounting firms become independent and always maintain their image in the business environment. Companies will not replace large public accounting firms because they are able to generate credibility (quality, capability, or power to generate trust) in the company's financial statements in the eyes of investors and creditors. It can be concluded that companies that have used the services of a public accounting firm are unlikely to do auditor switching. This statement is supported by research conducted by Manto \& Wanda (2018) that the result of this study is the variable size of public accounting firms affects auditor switching.

\section{$\mathrm{H}_{2}$ : the size of the public accounting firm has an effect on auditor switching}

If financial distress is associated with audit opinion and auditor switching, then companies that are experiencing financial distress accompanied by the provision of an audit opinion other than unqualified tend to change auditors. 
The company will look for an auditor according to the financial condition and obtain an audit opinion that matches the wishes of management with the aim of recovering the company from difficulties in financial problems. This statement is supported by research conducted by Ikmala (2018) that the result of this study is financial distress is able to moderate audit opinions on auditor switching.

\section{$H_{3}:$ financial distress is able to moderate audit opinion on auditor} switching

If financial distress is related to the size of the public accounting firm and audit switching, then companies that are experiencing financial distress will tend to change auditors to reduce audit fees. Companies will look for smaller auditors if the company incurs high audit fees. This statement is supported by research conducted by Ikmala (2018) that the result of this study is financial distress is able to moderate the size of public accounting firms towards auditor switching.

$\mathrm{H}_{4}$ : financial distress is able to moderate the size of public accounting firm size on auditor switching

\section{Method}

This study used quantitative data sourced from secondary data obtained from the site www.idx.co.id. The data collection techniques were based on documentary techniques. The population in this study was all companies listed on the Jakarta Islamic Index for the 2014-2019 period. The method used in determining the sample was a purposive sampling method, which is a sampling technique that uses judgmental sampling to determine specific criteria for the sample. The criteria for the companies that were used as samples were: a) Companies listed on the Jakarta Islamic Index during 20142019. b) Companies that publish financial statements that have been audited completely and consecutively. 
Choirul Huda, Ratno Agriyanto, Herwening Sindu Lestari, Bill Pangayow

Table 1. Criteria for Determining Research Samples

JIAFR | 164

\begin{tabular}{clc}
\hline No & \multicolumn{1}{c}{ Information } & Number \\
\hline 1 & Companies listed on the Jakarta Islamic Index during 2014-2019 & 12 \\
2 & $\begin{array}{l}\text { Companies that do not publish completely audited financial } \\
\text { statements consecutively }\end{array}$ & $10)$ \\
\hline Number of sample companies & 12
\end{tabular}

Source: processed data, 2021

There were 12 companies listed on the Jakarta Islamic Index during 2014-2019 and all of these companies published financial statements that had been audited in full and successively. Based on the predetermined sample criteria, there were 12 companies used in the study, so that the number of observations for 6 years was 72 .

\section{Results and Discussion}

Descriptive statistical analysis is used to provide an overview or describe the variable data used in the study. The following is the result of a descriptive analysis including the frequency distribution table, minimum value, maximum value, mean, and standard deviation.

Based on table 2, it could be seen that $93.1 \%$ of companies registered in JII for the 2014-2019 period did not change auditors, while 6.9\% companies did auditor changes. Of the 72 samples studied, 5 companies were known to change auditors, the remaining 67 companies did not change auditors.

Table 2. Auditor Switching

\begin{tabular}{llrrrr}
\hline & Frequecy & Percent & $\begin{array}{c}\text { Valid } \\
\text { Percent }\end{array}$ & $\begin{array}{c}\text { Cumulatie } \\
\text { Percent }\end{array}$ \\
\hline Valid & Not doing auditor switching & 67 & 93.1 & 93.1 & 93.1 \\
& Perform auditor switching & 5 & 6.9 & 6.9 & 100.0 \\
\hline & Total & $\mathbf{7 2}$ & $\mathbf{1 0 0 . 0}$ & $\mathbf{1 0 0 . 0}$ &
\end{tabular}

Source: processed data, 2021 
Financial distress as a moderating variable of the influence of audit opinion ...

Table 3. Audit Opinion

\begin{tabular}{llrrrr}
\hline & Frequency & Percent & $\begin{array}{c}\text { Valid } \\
\text { Percent }\end{array}$ & $\begin{array}{c}\text { Cumulatie } \\
\text { Percent }\end{array}$ \\
\hline Valid & $\begin{array}{l}\text { Did not get an unqualified } \\
\text { opinion } \\
\text { get an unqualified opinion }\end{array}$ & 17 & 23.6 & 23.6 & 23.6 \\
& 55 & 76.4 & 76.4 & 100.0 \\
\hline Total & $\mathbf{7 2}$ & $\mathbf{1 0 0 . 0}$ & $\mathbf{1 0 0 . 0}$ & \\
\hline
\end{tabular}

Source: processed data, 2021

Table 4. Public Accounting Firm Size

\begin{tabular}{llrrrr}
\hline & Frequency & Percent & $\begin{array}{c}\text { Valid } \\
\text { Percent }\end{array}$ & $\begin{array}{c}\text { Cumulate } \\
\text { Percent }\end{array}$ \\
\hline Valid & $\begin{array}{l}\text { do not use the services of } \\
\text { the Big Four }\end{array}$ & 11 & 15.3 & 15.3 & 15.3 \\
$\begin{array}{l}\text { use the services of the Big } \\
\text { Four }\end{array}$ & 61 & 84.7 & 84.7 & 100.0 \\
\hline$\quad$ Total & $\mathbf{7 2}$ & $\mathbf{1 0 0 . 0}$ & $\mathbf{1 0 0 . 0}$ & \\
\hline
\end{tabular}

Source: processed data, 2021

Based on table 3, it could be seen that $23.6 \%$ of companies registered in JII for the 2014-2019 period did not get an unqualified opinion, 76.4\% of companies received an unqualified opinion. Of the 72 samples studied, 55 companies were known to get an unqualified opinion, the remaining 17 companies did not get an unqualified opinion.

Based on table 4 , it could be seen that $15.3 \%$ of companies registered in JII for the period 2014-2019 did not use the services of the Big Four public accounting firm, $84.7 \%$ of the companies used the services of the Big Four public accounting firm. Of the 72 samples studied, 61 companies were known to use the services of the Big Four public accounting firm, the remaining 11 companies did not use the services of the Big Four public accounting firms. 
Choirul Huda, Ratno Agriyanto, Herwening Sindu Lestari, Bill Pangayow

Table 5. Financial Distress

\begin{tabular}{lrr}
\hline N & Valid & 72 \\
& Missing & 0 \\
Mean & & 3.4867 \\
Std. Deviation & & 1.92080 \\
Minimum & .61 \\
Maximum & & 8.86 \\
\hline
\end{tabular}

Source: processed data, 2021

Table 6. Hosmer and Lemeshow Test

\begin{tabular}{llll}
\hline Step & Chi-square & Df & Sig. \\
\hline 1 & 2,576 & 8 & .958 \\
\hline
\end{tabular}

Source: processed data, 2021

Based on the table of public accounting firm size variables in this study, the results obtained were: a minimum value of 0.61 , a maximum value of 8.86, an average value of 3.4867 and a standard deviation of 1.92080 . The average value of 3.4867 showed that most companies did not experience financial distress. The minimum value of 0.61 described that the company was experiencing financial distress, while the maximum value of 8.86 described that the company was having sound financial management.

Table 6 show the results with the value of Hosmer and Lemeshow's Goodness of Fit Test of 2.576 with a significant probability of 0.928 , the value was greater than 0.05 . Based on the results above, it can be concluded that the null hypothesis is accepted or the model is able to predict the observed value. Thus, the regression model can be used for further analysis.

Table 7. Overall Model Fit

\begin{tabular}{ll}
\hline $\begin{array}{l}-2 \text { Log Likelihood (-2LL) at start (Block } \\
\text { Number }=0 \text { ) }\end{array}$ & $\begin{array}{l}-\mathbf{2} \text { Log Likelihood (-2LL) at the end (Block } \\
\text { Number }=\mathbf{1})\end{array}$ \\
\hline 36,317 & 17.293 \\
\hline Source: processed data, 2021 &
\end{tabular}


Financial distress as a moderating variable of the influence of audit opinion ...

Table 8. Model Summary

\begin{tabular}{lllc}
\hline Step & $\mathbf{- 2}$ Logs likelihood & Cox \& Snell R Square & Nagelkerke R Square \\
\hline 1 & $17.293 a$ & .232 & .586 \\
\hline
\end{tabular}

Source: processed data, 2021

JIAFR | 167

Table 9. Classification

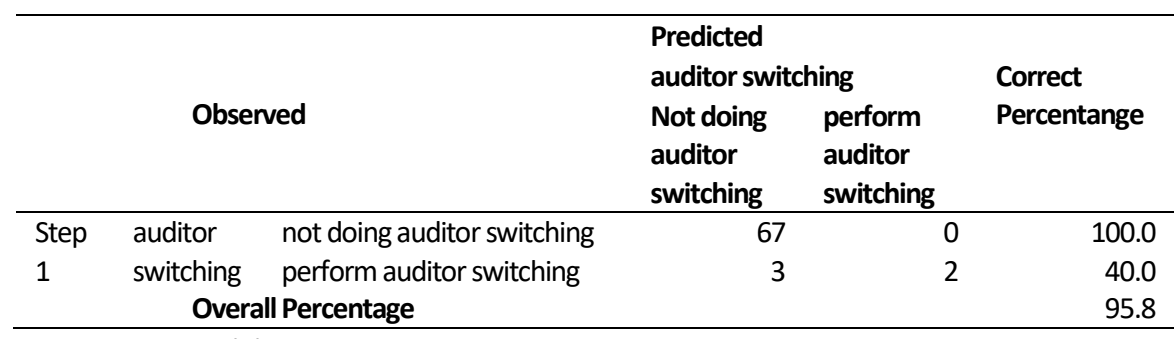

Source: processed data, 2021

Table 8 show decrease in value of-2Log Likelihood (-2LL) at the beginning (Block Number $=0$ ) to -2 Log Likelihood $(-2 \mathrm{LL}$ ) at the end (Block Number $=1$ ). It can be concluded that the overall fit model is a good regression model or the hypothesized model fits the data.

The value of the coefficient of determination (R2) or Negelkerke R Square was 0.586 . This value described the ability of the independent variable in the form of audit opinion, public accounting firm size and financial distress moderator variable in influencing the dependent variable of auditor switching in companies listed on the Jakarta Islamic Index during 2014-2019 amounting to $58.6 \%$. The remaining $41.4 \%$ was another variable that can affect auditor switching but was not used in this study.

Based on the table 9, the test results show that the predictive power of the regression model for the possibility of a company changing auditors was $40 \%$. The predictive power of the regression model for companies that did not change auditors was $100 \%$, meaning that out of a total of 67 companies, it was predicted that they would not change auditors. Overall, that $95.8 \%$ of this sample could be predicted accurately using the logistic regression model. 
Choirul Huda, Ratno Agriyanto, Herwening Sindu Lestari, Bill Pangayow

Table 10. Logistics Regression Coefficient Test Results

\begin{tabular}{|c|c|c|c|c|c|c|c|}
\hline & & B & SE & Wald & Df & Sig. & $\operatorname{Exp}(B)$ \\
\hline Step & $\mathrm{x} 1$ & $-13,378$ & 12,395 & 1.165 & 1 & .280 & .000 \\
\hline \multirow[t]{4}{*}{$1 a$} & $x 2$ & 13,474 & 12643 & 1,136 & 1 & .287 & 7.108E5 \\
\hline & $x 1 \times 3$ & 3.505 & 3,935 & .793 & 1 & .373 & 33,268 \\
\hline & $x 2 \times 3$ & -4.910 & 4.133 & 1.412 & 1 & .235 & .007 \\
\hline & Constant & -.991 & .842 & 1.387 & 1 & .239 & .371 \\
\hline
\end{tabular}

Source: processed data, 2021

Based on table 10, the logistic regression model equations formed based on the estimated parameter values in this study were

$$
\begin{aligned}
& \text { SWITCH }=-.991-13,3780 \text { PINION + 13,474UKAP + 3.505OPINION*FD - } \\
& \text { 4.910UKAP*FD + e }
\end{aligned}
$$

Based on the regression model formed, the results can be interpreted as follows. The first hypothesis stated that the audit opinion variable had a regression coefficient value of $-13,378$ and the significant value for the audit opinion variable was 0,280 . This number is greater than the research alpha value $(0,280>0.05)$ so the conclusion is that the first hypothesis is rejected. This means that the audit opinion has no significant effect on auditor switching in companies listed on the JII for the 2014-2019 period.

The second hypothesis stated that the public accounting firm size variable had a regression coefficient value of 13,474 and the significant value for public accounting firm (KAP) size variable was 0,287 . This number is greater than the research alpha value $(0,287>0.05)$, so the conclusion is that the second hypothesis is rejected. This means that the size of the public accounting firm has no significant effect on auditor switching in companies listed on the JII for the 2014-2019 period.

The third hypothesis stated that the variables that interacted between audit opinion and financial distress had a regression coefficient value of 3,505 and the significant value for variables that interacted between audit opinion and financial distress was 0,373 . This number is greater than the research 
alpha value $(0,373>0.05)$, so the conclusion for the third hypothesis is rejected. This means that financial distress does not moderate audit opinion on auditor switching in companies listed on JII for the 2014-2019 period.

The fourth hypothesis stated that the value of the regression coefficient on the interaction variable of public accounting firm size with financial JIAFR | 169 distress produced a value of $-4,910$ and the significant value for the variable that interacted between public accounting firm size and financial distress was 0,235 . This number is greater than the research alpha value $(0,235>0.05)$, so the conclusion for the fourth hypothesis is rejected. This means that financial distress does not moderate public accounting firm size on auditor switching in companies listed in JII for the 2014-2019 period.

\section{Effect of Audit Opinion on Auditor Switching}

The results of the study provide evidence that the audit opinion has no effect on auditor switching in companies listed on the JII for the 2014-2019 period. This means that companies tend not to do auditor switching even though they do not get an unqualified audit opinion. These results are not in accordance with the results of research conducted by Yusriwarti, (2019), Susanto, (2018) and Ikmala (2018) that audit opinion variables affect auditor switching. The result in accordance with this study is research conducted by Wea \& Murdiawati (2015) that audit opinion has no effect on audit switching. The companies will continue to use the services of the old public accounting firm if the public accounting firm can provide a good opinion for them. The goal is that companies can improve the quality of financial reports in the eyes of financial statement users such as creditors, investors and potential investors. According to Pasaribu \& Suprapto (2020) if the companies get an opinion other than unqualified opinion, it is likely that the companies prefer to improve its operating activities and accounting reporting system so as to produce financial statements that are free from material misstatement. 
Choirul Huda, Ratno Agriyanto, Herwening Sindu Lestari, Bill Pangayow

\section{The Effect of Public Accounting Firm Size on Auditor Switching}

The results of the study provide evidence that the public accountant firm size has no effect on auditor switching in companies listed on the JII for the 2014-2019 period. This means that companies tend not to do auditor switching even though the they do not use public accounting firm services in collaboration with Big Four public accounting firms. Basically, public accounting firms that do not cooperate with Big Four public accounting firms also have a good reputation. The companies will continue to use the services of public accounting firms that do not cooperate with the Big Four public accounting firms because the companies are already comfortable with the services provided. Although in the future the companies will conduct auditor switching, this is due to regulations regarding auditor rotation.

These results are not in accordance with the results of research conducted by Manto \& Wanda (2018) and Yusriwarti (2019) that the public accounting firm size affects auditor switching. The result in accordance with this study is research conducted by Putra \& Suryanawa (2016) that public accounting firm size has no effect on audit switching. It was found that the companies that do not do auditor switching in determining the choice of using public accounting firm do not see from how big the public accounting firm is rather they see from the level of quality possessed by the public accounting firm. According to Jessica (2014) both public accounting firms from Big Four and non Big Four still provide audit quality in accordance with the audit standards that have been set so that the size of the public accounting firm does not determine auditor turnover by the companies with the reason to get better audit quality.

\section{The Effect of Financial Distress in Moderating Audit Opinion on Auditor}

\section{Switching}

The results of the study provide evidence that financial distress is not able to moderate audit opinion on auditor switching in companies listed on JII for the 2014-2019 period. This means that companies tend not to change auditors even though the they do not get an unqualified audit opinion. In 
companies experiencing financial distress, many indicators of going concern are found. It is likely that the auditor will give a going concern opinion on the company so that it can affect a negative point of view for users of financial statements in determining the decisions taken. The reason for not doing auditor switching is to bind the old auditors to maintain the trust of investors and creditors as providers of capital.

These results are not in accordance with the results of research conducted by Chadegani et al. (2011) that the financial distress variable is able to moderate audit opinion on auditor switching. The result in accordance with this study is research conducted by Putra \& Suryanawa (2016) that financial distress is not able to moderate audit opinion on auditor switching. It is assumed that companies that do not get an unqualified opinion then perform auditor switching when they are experiencing financial distress will only give negative assumptions for the companies to users of financial statements. It is feared that the companies will commit fraud in the form of manipulation of financial statements when the companies get an auditor who can be invited to cooperate. According to Nasir (2018) when the company is in financial distress, it is likely that the company will get an opinion other than an unqualified opinion, but in this case, the company will not perform auditor switching because the published opinion is based on an agreement between the auditor and the client, so the auditor's opinion is in accordance with the client's request.

\section{The Effect of Financial Distress in Moderating the Size of Public Accounting Firm on Auditor Switching}

The results of the study provide evidence that financial distress is not able to moderate public accounting firm size on auditor switching in companies listed on JII for the 2014-2019 period. This means that companies that use public accounting firm services in collaboration with Big Four public accounting firms tend not to do auditor switching when the company is experiencing an unhealthy financial condition. The conditions experienced by the companies make them have no choice to do auditor switching. The 
companies will continue to use the services of the old public accounting firm so that the audit fee is not greater than the audit fee when using the new public accounting firm. Moving to a new public accounting firm, the auditor will seek information and understand the new business related to the companies.

These results are in accordance with the results of research conducted by Putra \& Suryanawa (2016) that the financial distress variable is not able to moderate the effect of public accounting firm size on auditor switching. The researchers think that companies are better off using their finances to increase capital than paying large audit fees for the change of a new public accounting firm. The reason is to improve the conditions experienced by the companies in the form of financial distress. According to Ikmala (2018), public accounting firms that have collaborated with Big Four public accounting firms will reduce companies in making public accounting firm changes. When the company experiences financial difficulties, the company will not perform auditor switching because the company already uses a public accounting firm that has a good reputation.

\section{Conclusion}

Based on the discussion of the research results that have been carried out, it can be concluded that the audit opinion has no effect on auditor switching. If the auditor gives a good opinion, the company will continue to use the old public accounting firm. Public accounting firm size has no effect on auditor switching. The company will continue to use the old public accounting firm even though it is not the Big Four public accounting firm. Financial distress is not able to moderate audit opinion on auditor switching. Companies that are experiencing unhealthy financial problems, do not change auditors even though they do not get an unqualified opinion. Financial distress is not able to moderate public accounting firm size on auditor switching. Companies that are experiencing financial problems are not healthy and do not change the old public accounting firm to Big Four public accounting firm. The implications of the research results are expected to be able to motivate management in 
maintaining or changing auditors based various factors including audit opinion, public accounting firm size and financial distress. Companies can improve the quality of financial reports better by not changing auditors. By understanding several factors that influence auditor turnover, the quality of financial reports and the companies' reputation can be maintained properly. Based on the conclusions that have been made, it is recommended for further research on several things including increasing the sample of companies, extending the time span or changing the type of research object so that more data is obtained and is able to answer factors that affect auditor changing.

\section{References}

Chadegani, Mohamed, \& Jari. (2011). The Determinant Factors of Auditor Switch among companies listed on Tehran stock exchange. International Research Journal of Finance and Economics, 80(80), 158168.

Govindarajan, V. (1986). Impact of Participation in The Budgetary Process on Managerial Attitudes and Performance: Universalitic and Contingency Perspective. Decision Sciences, 17(4), 496-516.

Halim, A. \& Mahmud, M. H. (1997). Analisis Laporan Keuangan. Yogyakarta: AMP YKPN.

Ikmala, R. R. (2018). Financial Distress sebagai Pemoderasi Pengaruh Opini Audit, Reputasi Kantor Akuntan Publik, dan Fee Audit Terhadap Auditor Switching (Studi Empiris pada Perusahan Manufaktur yang Terdaftar di BEI Periode 2011 - 2017). Skripsi. Program Studi Akuntansi Fakultas Ekonomi Dan Bisnis Universitas Muhammadiyah Magelang.

Jensen, M. C., \& Meckling, W. H. (1976). Theory of The Firm: Managerial Behavior, Agency Costs and Ownership Structure. Journal of Financial Economics, 3(4), 305-360.

Jessica. (2014). Analisis Pengaruh Ukuran Kap, Ukuran Perusahaan, Financial Distress, Audit Delay, Opini Audit, Dan Pergantian Manajemen Terhadap Auditor Switching. https://www.atmajaya.ac.id 11 Agustus 2021.

Kieso, Donald E., Weygandt, Jerry J., \& Warfield, T. D. (2007). Akuntansi Intermediate. Jakarta: Penerbit Salemba Empat. 
Choirul Huda, Ratno Agriyanto, Herwening Sindu Lestari, Bill Pangayow

Manto, J. I., \& Wanda, D. L. (2018). Pengaruh Financial Distress, Pergantian Manajemen Dan Ukuran Kap Terhadap Auditor Switching. Media Riset Akuntansi, Auditing \& Informasi, 18(2), 205.

Mardiyah, A. (2003). Pengaruh Faktor Klien dan Faktor Auditor terhadap

JIAFR | 174 Auditor Changes. Media Riset Akuntansi, 3(2), 133-154.

Mulyadi. (2014). Auditing. Jakarta: Salemba Empat.

Nasir, A. (2018). Pengaruh Opini Audit, Pergantian Manajemen dan Fee Audit Terhadap Auditor Switching dengan Financial Distress sebagai Variabel Moderasi. Journal of Materials Processing Technology, 1(1), 18.

Nasser, et al. (2006). Auditor Client Relationship: The Case of Audit Tenura and Auditor Switching in Malaysia. Managerial Auditing Journal, 21(7), 724-737.

Oktaviana, Z., Suzan, L., \& Yudowati, S. P. (2017). Pengaruh ukuran KAP , opini audit dan pergantian manajemen terhadap Auditor Switching (Studi pada Perusahaan BUMN yang terdaftar di BEI 2010-2016). EProceding of Management, 4(2), 16-43.

Pasaribu, \& Suprapto. (2020). Pengaruh Financial Distress, Opini Audit, Audit Delay dan Biaya Audit Terhadap Auditor Switching. Skripsi. Program Studi Akuntansi, Fakultas Ekonomi dan Bisnis Universitas Islam Bandung.

Putra, I., \& Suryanawa, I. (2016). Pengaruh Opini Audit Dan Reputasi Kap Pada Auditor Switching Dengan Financial Distress Sebagai Variabel Moderasi. E-Jurnal Akuntansi, 14(2), 1120-1149.

Qoyum, A. (2018). Lembaga Keuangan Islam di Indonesia. Yogyakarta: Elmatera.

Riyatno. (2007). Pengaruh Ukuran Kantor Akuntan Publik. Jurnal Keuangan Dan Bisnis, 5(2), 148-162.

Susanto, Y. K. (2018). Auditor Switching: Management Turnover, Qualified Opinion, Audit Delay, Financial Distress. International Journal of Business, Economics and Law, 15(5), 152-132.

Wawo, A., Nurdin, E., \& Yusran, S. (2017). Pengaruh Opini Audit Dan Reputasi Auditor Terhadap Voluntary Auditor Switching (Studi Pada Perusahaan Real Estate Dan Property Yang Terdaftar Di Bursa Efek Indonesia). Jurnal Akuntansi dan Keuangan, 2 (2), 49-60. 
Financial distress as a moderating variable of the influence of audit opinion ...

Wea, A. N. S., \& Murdiawati, D. (2015). Faktor-Faktor Yang Mempengaruhi Auditor Switching Secara Voluntary Pada Perusahaan Manufaktur. Journal of Physics A: Mathematical and Theoretical, 44(8), 085201.

Yusriwarti. (2019). Pengaruh Opini Audit, Financial Distres dan Ukuran Perusahaan terhadap Auditor Switching pada Perusahaan yang terdaftar di BEI.Jurnal Akuntansi Dan Keuangan, 8(1), 94-109. 
JIAFR | 176 